Ruminta $\cdot$ T. Nurmala $\cdot$ Y. Yuwariah $\cdot$ N.Y. Pratiwi

\title{
Respon pertumbuhan dan hasil tanaman hanjeli pada panen awal akibat pemberian dosis pupuk biosilika dan paklobutrazol di lahan kering Jatinangor
}

\section{Growth and yield of job tears at early harvest due to application of biosilica fertilizer and paclobutrazol in Jatinangor dry land}

Diterima : 20 Agustus 2018/Disetujui : 10 Desember 2018 / Dipublikasikan : 31 Desember 2018

CDepartment of Crop Science, Padjadjaran University

\begin{abstract}
Job's tears (Coix lacryma-jobi L.) are one of alternative food crops and functional crops. Job's tears has not been popular in farmers because crops are tall, long life, and low productivity. This study aims to determine the dosage of biosilica fertilizer and concentration of paclobutrazol which can give the best effect on growth and yield of job's tears at early harvest. The experiment was conducted from August 2017 - January 2018, at Ciparanje research station, Padjadjaran University, Jatinangor, Sumedang. This research used Split Plot Design. Main plot was dosages of biosilica $(0 \mathrm{~kg} / \mathrm{ha}, 100$ $\mathrm{kg} / \mathrm{ha}$; $200 \mathrm{~kg} / \mathrm{ha}$ ), and subplot was paclobutrazol concentrations (0 ppm, 1250 ppm, 1500 ppm) with three replications. The results showed that there was no interaction between biosilica and paclobutrazol. Treatment without biosilica fertilizer gave a significant effect on the number of leaf at 10 weeks after planting. The treatment of paclobutrazol did not have a significant effect on the growth and yield of job's tears.
\end{abstract}

Keywords: Biosilica fertilizer · Job's tears • Paclobutrazol

Sari. Hanjeli (Coix lacryma-jobi L) merupakan salah satu tanaman pangan alternatif dan tanaman fungsional. Hanjeli belum sepenuhnya dimanfaatkan petani salah satunya karena tanaman yang cukup tinggi dan memiliki umur cukup lama. Penelitian ini bertujuan untuk mengetahui dosis pupuk biosilika dan konsentrasi paklobutrazol yang dapat memberikan pengaruh terbaik terhadap pertumbuhan dan

\footnotetext{
Dikomunikasikan oleh Anne Nuraini

Ruminta $^{1}$. T. Nurmala ${ }^{1}$. Y. Yuwariah ${ }^{1}$. N.Y. Pratiwi

${ }^{1}$ Fakultas Pertanian Universitas Padjadjaran

Korespondensi: r_ruminta@yahoo.com.
}

hasil tanaman hanjeli pulut dipanen awal (matang kuning). Penelitian dilaksanakan bulan Agustus 2017-Januari 2018 di Ciparanje, Universitas Padjadjaran, Jatinangor, Sumedang. Rancangan percobaan yang digunakan adalah rancangan petak terbagi yang terdiri dari petak utama pupuk biosilika dengan dosis $0 \mathrm{~kg} / \mathrm{ha}$; $100 \mathrm{~kg} / \mathrm{ha} ; 200 \mathrm{~kg} / \mathrm{ha}$ dan anak petak paklobutrazol dengan konsentrasi 0 ppm; 1250 ppm; 1500 ppm, diulang tiga kali. Hasil percobaan menunjukkan bahwa tidak ada interaksi antara pupuk biosilika dan paklobutrazol terhadap komponen pertumbuhan dan hasil tanaman hanjeli. Perlakuan tanpa pupuk biosilika memberikan hasil yang sama dengan pupuk biosilika $100 \mathrm{~kg} / \mathrm{ha}$ pada jumlah daun 10 MST. Pemberian paklobutrazol tidak memberikan pengaruh nyata terhadap komponen pertumbuhan dan hasil tanaman hanjeli pulut.

Kata kunci: Hanjeli (Coix lacryma-jobi L) • Pupuk biosilika $\cdot$ Paklobutrazol

\section{Pendahuluan}

Kebutuhan akan konsumsi beras di Indonesia cukup tinggi, menurut Survei Sosial Ekonomi Nasional oleh Badan Pusat Statistik (2015) menunjukkan bahwa konsumsi beras per kapita tahun 2015 adalah sebesar 98 kilogram per tahun. Jumlah ini meningkat dibanding tahun sebelumnya yang hanya $97,2 \mathrm{~kg}$ per tahun. Konsumsi beras yang sudah menjadi ketergantungan masyarakat Indonesia dapat dialihkan dengan mengonsumsi komoditas pangan selain beras (diversifikasi pangan) seperti terigu (gandum), hanjeli, sorghum, dan sagu. Hanjeli (Coix lacryma-jobi L.) merupakan 
salah satu jenis serealia pangan alternatif. Hanjeli dimanfaatkan sebagai pangan, pakan, obat dan bahan baku industri (Nurmala, 1998). Biji hanjeli memiliki kandungan gizi yang cukup tinggi diantaranya pada kandungan protein $(14,1 \%)$, lemak $(7,9 \%)$, vitamin $B_{1}(0,48 \%)$ serta kandungan kaslium (54\%) lebih tinggi daripada beras (Nurmala dan Irwan, 2007)

Salah satu teknik budidaya yang penting dan sangat mempengaruhi hasil tanaman yaitu pemupukan. Pemupukan berfungsi sebagai penyedia nutrisi dalam tanah untuk pertumbuhan tanaman. Pupuk silika dikenal sebagai unsur hara yang bermanfaat terutama untuk tanaman padi dan tebu (Balai Penelitian Tanah, 2010). Unsur hara silika berfungsi memperkuat dinding jaringan epidermis dan jaringan pembuluh, menghambat infeksi jamur, bentuk daun yang tegak (tidak terkulai) sehingga daun efektif untuk melakukan fotosintesis. Tanaman cukup Si memiliki daun yang terlapisi silikat dengan baik, lebih tahan terhadap serangan berbagai penyakit yang diakibatkan oleh fungi maupun bakteri seperti blas, perakaran tanaman lebih kuat (Makarim dkk., 2007).

Paklobutrazol merupakan senyawa yang dapat menghambat pertumbuhan tanaman (Rubiyanti, 2015). Paklobutrazol menghambat produksi giberelin di dalam tubuh tanaman, yang berperan dalam proses pemanjangan sel selanjutnya dapat menyebabkan pengurangan kecepatan pembelahan sel, pengurangan pertumbuhan vegetatif dan akan mengalihkan asimilat ke pertumbuhan reproduktif untuk pembentukan bunga (Weaver, 1972 dalam Aztrina, 2014). Menurut penelitian Marimbing (2003) pemberian paklobutrazol mempengaruhi tinggi tanaman padi, tanaman padi yang diaplikasikan paklobutrazol sampai dengan 1500 ppm dapat menekan pertambahan tinggi tanaman padi.

Permasalahan tanaman hanjeli lainnya adalah umur tanaman yang cukup lama. Pada umumnya petani melakukan panen setelah lewat masak fisiologis, sehingga mutu benih yang dihasilkan telah menurun (Kartika dan Ilyas, 1994). Oleh karena itu pada penelitian ini dilakukan panen matang kuningsebelum masak fisiologis dengan tujuan untuk mempercepat pemanenan dan melihat pengaruhnya terhadap hasil tanaman hanjeli.

\section{Bahan dan Metode}

Penelitian dilaksanakan di Jatinangor, Kabupaten Sumedang, Jawa Barat. Waktu pelaksanaan percobaan dimulai pada bulan Agustus 2017 hingga Januari 2018. Bahan yang digunakan adalah benih hanjeli pulut genotip 37 dari Laboratorium Teknologi Produksi Tanaman, biosilika dari jerami padi, paklobutrazol, pupuk $\mathrm{N}$, P, dan $\mathrm{K}$, dan pestisida. Alat yang digunakan yaitu alat pertanian (tugal, cangkul, arit, kored, ember, emerat), alat tulis, alat ukur (penggaris atau meteran), patok, timbangan analitik, kamera, leaf area meter, soil mouisture meter, seed counting, mesin penyosoh biji hanjeli, dan oven.

Percobaan ini dilakukan menggunakan rancangan Petak Terbagi dengan pupuk biosilika digunakan sebagai petak utama (Main Plot) yang terdiri dari tiga dosis (tanpa pupuk biosilika, $100 \mathrm{~kg} / \mathrm{ha}$, dan $200 \mathrm{~kg} / \mathrm{ha}$ ) dan paklobutrazol sebagai anak petak (Sub Plot) terdiri dari tiga konsentrasi (tanpa paklobutrazol, 1250 ppm, dan 1500 ppm). Setiap perlakuan diulang 3 kali sehingga terdapat 27 satuan percobaan. Selain perlakuan percobaan, semua kegiatan lain di lapangan, seperti persiapan lahan, persiapan benih, penanaman, penyulaman, pemupukan, penyiraman, penyiangan gulma, pengendalian hama dan penyakit, dan panen awal (matang kuning) serta pasca panen diperlakukan sama. Parameter yang diamati pada percobaan ini adalah kadar air biji, umur berbunga, tinggi tanaman, jumlah daun, jumlah srisip, jumlah malai, bobot biji per rumpun, hasil, dan rendeman biji pecah kulit (RBPK). Data hasil pengamatan dianalisis menggunakan Software SPPS 18. Perbedaan pengaruh perlakuan diketahui menggunakan Uji Duncan pada taraf nyata $5 \%$.

\section{Hasil dan Pembahasan}

Kadar Air Biji dan Umur Berbunga. Kadar air biji dan umur berbunga merupakan pengamatan penunjang tidak dijui secara statistik. Kadar air biji panen matang kuning (Tabel 1) menun-jukkan bahwa kadar air tersebut termasuk kedalam ratarata kadar air panen tanaman serealia lainnya dengan rata-rata kadar air sebesar 38,09\%. Kadar air biji hanjeli terendah yaitu sebesar $24 \%$ dan 
kadar air biji hanjeli tertinggi sebesar 47,72\%. Seperti pada biji tanaman serealia lainnya, biji hanjeli panen matang kuning harus dikeringkan terlebih dahulu untuk selanjutnya masuk ke tahap penggilingan. Penjemuran biji hanjeli panen matang kuning memerlukan waktu sekitar 2-3 minggu.

Kadar air biji hanjeli pada panen fisiologis (setelah biji dikeringkan selama kurang lebih 34 minggu) lebih rendah dibandingkan dengan kadar air panen awal. Kadar air panen fisiologis lebih rendah karena panen dilakukan sesuai dengan umur tanaman sehingga proses pengeringan benih terjadi pada tanaman sebelum dipanen. Kadar air biji hanjeli tertinggi pada panen fisiologis yaitu sebesar 16,37 \% sedangkan kadar air biji terendah sebesar 10,98\%. Pemberian pupuk biosilika dan paklobutrazol tidak memberikan pengaruh terhadap kadar air biji panen matang kuningdan fisiologis.

Pada Tabel 1 terlihat bahwa umur berbunga tanaman hanjeli rata-rata 92,88 HST. Pemberian pupuk biosilika dan paklobutrazol tidak memberikan pengaruh terhadap umur berbunga dan umur panen tanaman hanjeli. Pada deskripsi tanaman hanjeli memiliki umur berbunga 12 MST. Pada percobaan ini umur berbunga tanaman hanjeli lebih lama yaitu 13 MST. Umur berbunga dipengaruhi oleh faktor lingkungan dan faktor genetik. Masa vegetatif akhir menuju generatif terjadi pada bulan yang memiliki curah hujan cukup tinggi. Pada saat curah hujan tinggi maka cahaya matahari sedikit (mendung) sehingga diduga fotosintesis terhambat. Apabila pada akhir fase vegetatif fotosintesis terhambat akan menyebabkan masa generatif juga terhambat.

Tanaman hanjeli merupakan tanaman C4 yang menghendaki cahaya matahari yang penuh dan penyinaran lebih lama. Menurut Sutoyo (2011) tanaman berhari panjang apabila mendapatkan penyinaran yang lebih pendek akan cenderung menghambat pembungaan. Pada penelitian ini umur berbunga tanaman hanjeli adalah 13 MST. Menurut Nurmala dan Irwan (2007) tanaman hanjeli pulut berbunga pada umur 68-132 HST dan umur panen ratarata 165 HST. Umur panen pada percobaan ini adalah 22 MST (154 HST). Umur panen akan mempengaruhi kadar air biji. Kadar air biji panen matang kuning (Tabel 1) menunjukkan kadar air biji hanjeli yang relatif tinggi berkisar antara $24 \%$ hingga 47,72 \%. Hal tersebut menunjukkan pada panen matang kuning masih mengandung air yang cukup banyak.
Tabel 1. Kadar air biji hanjeli panen matang kuning dan umur berbunga.

\begin{tabular}{cccc}
\hline Perlakuan & $\begin{array}{c}\text { Kadar Air } \\
\text { Panen } \\
\text { Awal }(\%)\end{array}$ & $\begin{array}{c}\text { Kadar Air } \\
\text { Panen } \\
\text { Fisiologis } \\
(\%)\end{array}$ & $\begin{array}{c}\text { Umur } \\
\text { Berbunga } \\
(\text { HST })\end{array}$ \\
\hline A & 40,74 & 15,66 & 94 \\
B & 47,36 & 16,04 & 93 \\
C & 34,04 & 10,98 & 94 \\
D & 47,72 & 15,52 & 92 \\
E & 24,00 & 16,37 & 91 \\
F & 33,33 & 14,64 & 93 \\
G & 46,00 & 15,50 & 93 \\
H & 33,33 & 15,28 & 92 \\
I & 36,36 & 15,31 & 96 \\
\hline Rata-rata & 38,09 & 15,03 & 92,88 \\
\hline Keterangan & A & & \\
\hline
\end{tabular}

Keterangan: A=Tanpa biosilika+tanpa paklobutrazol (Kontrol), B=Tanpa biosilika+paklobutrazol 1250 ppm, C=Tanpa biosilika+paklobutrazol 1500 ppm,D=Biosilika $100 \mathrm{~kg} /$ ha+tanpa paclobutrazol, $\mathrm{E}=$ Biosilika $100 \mathrm{~kg} / \mathrm{ha}+$ paklobutrazol $1250 \mathrm{ppm}$. F=Biosilika $100 \mathrm{~kg} / \mathrm{ha}+$ paklobutrazol $1500 \mathrm{ppm}, \mathrm{G}=$ Biosilika $200 \mathrm{~kg} /$ ha+tanpa paclobutrazol, H=Biosilika $200 \mathrm{~kg} /$ ha+paklobutrazol 1250 ppm, I=Biosilika 200 $\mathrm{kg} /$ ha+paklobutrazol 1500 ppm

Tinggi Tanaman dan Jumlah Daun. Tidak terdapat interaksi antara perlakuan pupuk biosilika dan paklobutrazol terhadap semua komponen pertumbuhan dan hasil hanjeli panen awal. Perlakuan dosis pupuk biosilika maupun konsentrasi paklobutrazol tidak memberikan pengaruh nyata terhadap tinggi tanaman pada umur 20 MST (Tabel 2).

Tidak adanya pengaruh signifikan diduga pupuk biosilika belum sepenuhnya terlarut pada tanah karena pada saat pengaplikasian pupuk biosilika curah hujan rendah (42 $\mathrm{mm} /$ bulan). Apabila curah hujan rendah maka ketersediaan air pada lahan juga rendah dan menyebabkan proses penyerapan silika terhambat sehingga silika belum sepenuhnya larut pada tanah. Menurut Makarim dkk. (2007) unsur hara silika berfungsi memperkuat dinding jaringan epidermis dan jaringan pembuluh, bentuk daun yang tegak (tidak terkulai) sehingga daun efektif untuk melakukan fotosintesis. Menurut Nurmala dkk. (2017) pertambahan tinggi tanaman adalah pertambahan sel-sel karena asimilat meningkat.

Perlakuan paklobutrazol tidak memberikan pengaruh nyata pada tinggi tanaman hanjeli 20 MST. Menurut Rai dan Poerwanto (2008), pemberian paklobutrazol akan menghambat pertumbuhan tanaman, dengan menghambat 
hormon giberelin. Menurut Marshel dkk. (2015), paklobutrazol merupakan zat pengatur tumbuh menghambat kerja hormon giberelin sehingga membentuk cabang yang panjang bukunya lebih pendek.

Penyebab tinggi tanaman tidak berbeda nyata diduga karena faktor lingkungan pada saat pengaplikasian curah hujan cukup tinggi (463 mm/bulan). Menurut Sanchez et al. (1988) dalam Ningsih (2017), pemberian paklobutrazol melalui daun lebih mudah, praktis, dan cepat namun jangka waktu pengaruhnya terhadap tanaman bersifat sementara, membutuhkan beberapa kali penyemprotan untuk mempertahankan tingkat penghambatan yang diinginkan. Oleh karena itu, diduga pengaplikasian paklobutrazol satu kali pada percobaan ini, mekanisme kerja paklobutrazol dalam menghambat hormon giberelin kurang maksimal yang diakibatkan oleh curah hujan tinggi.

Tabel 2. Tinggi tanaman dan jumlah daun pada 20 MST.

\begin{tabular}{lcc}
\hline \multicolumn{1}{c}{ Perlakuan } & $\begin{array}{c}\text { Tinggi } \\
\text { Tanaman } \\
(\mathrm{cm})\end{array}$ & $\begin{array}{c}\text { Jumlah } \\
\text { Daun per } \\
\text { Rumpun }\end{array}$ \\
\hline Dosis Biosilika : & $239,75 \mathrm{a}$ & $167,53 \mathrm{a}$ \\
$0 \mathrm{~kg} / \mathrm{ha}$ & $243,42 \mathrm{a}$ & $143,34 \mathrm{a}$ \\
$100 \mathrm{~kg} / \mathrm{ha}$ & $226,06 \mathrm{a}$ & $112,12 \mathrm{a}$ \\
$200 \mathrm{~kg} / \mathrm{ha}$ & $239,19 \mathrm{a}$ & $133,27 \mathrm{a}$ \\
Konsentrasi Paklobutrazol : & $242,56 \mathrm{a}$ & $155,06 \mathrm{a}$ \\
$0 \mathrm{ppm}$ & $227,47 \mathrm{a}$ & $134,66 \mathrm{a}$ \\
$1250 \mathrm{ppm}$ & &
\end{tabular}

Keterangan: Nilai rata-rata perlakuan yang diikuti oleh huruf yang dan pada kolom yang sama menunjukkan tidak berbeda nyata berdasarkan uji jarak berganda Duncan pada taraf $5 \%$.

Hasil pengujian mengenai pengaruh dosis biosilika dan konsentrasi paklobutrazol terhadap jumlah daun dapat dilihat pada Tabel 2. Secara mandiri, perlakuan biosilika tidak memberikan pengaruh nyata pada jumlah daun 20 MST. Menurut Vasanthi et al. (2014) dalam Wicaksono dkk. (2016) silika dapat meningkatkan pembentukan klorofil. Apabila klorofil terbentuk dalam jumlah tinggi maka laju fotosintesis akan semakin cepat maka fotosintat yang dihasilkan akan semakin banyak.

Perlakuan paklobutrazol tidak memberikan pengaruh nyata terhadap jumlah daun tanaman hanjeli (Tabel 2). Menurut Chaney (2004), fungsi utama giberelin adalah menstimulasi perpanjangan sel. Menurut Marshel dkk. (2015), paklobutrazol merupakan zat pengatur tumbuh menghambat kerja hormon giberelin sehingga membentuk cabang yang panjang bukunya lebih pendek. Berdasarkan penyataan tersebut penghambatan hormon giberelin lebih mengarah kepada batang tanaman sehingga tidak mempengaruhi jumlah daun. Hal yang menyebabkan tidak berpengaruh nyata karena unsur hara di dalam tanah sudah tercukupi untuk pertumbuhan tanaman hanjeli. Menurut Nyakpa dkk. (1988), pembentukan daun pada tanaman sangat dipengaruhi oleh ketersedian unsur hara nitrogen dan fosfor tersedia untuk pertumbuhan tanaman.

Jumlah Srisip dan Jumlah Malai. Srisip merupakan cabang yang keluar dari ruas batang tanaman hanjeli (ketiak daun tanaman hanjeli). Pengaruh mandiri seluruh taraf pemberian pupuk biosilika tidak memberikan pengaruh nyata pada jumlah srisip per rumpun (Tabel 3). Hal tersebut diduga menurut Yelis (2011) dalam Nurmala dkk. (2016) jumlah srisip dipengaruhi oleh varietas yang digunakan. Hal lain yang mempengaruhi bahwa biosilika tidak berbeda nyata adalah kandungan $\mathrm{Si}$ dalam pupuk biosilika belum sepenuhnya terserap oleh tanaman karena pupuk biosilika merupakan pupuk yang berasal dari bahan organik. Tanaman menyerap unsur dalam bentuk anorganik, pupuk biosilika yang diberikan merupakan bahan organik sehingga memerlukan proses untuk merubah organik menjadi anorganik yang siap diserap oleh tanaman.

Perlakuan paklobutrazol secara mandiri tidak memberikan pengaruh nyata terhadap jumlah srisip tanaman hanjeli (Tabel 3). Hal tersebut diduga pemberian paklobutrazol dilakukan saat curah hujan tinggi $(463 \mathrm{~mm} /$ bulan) sehingga kemungkinan kurang terserap secara optimal oleh tanaman. Menurut Sanchez et al. (1988) dalam Ningsih (2017), pemberian paklobutrazol melalui daun jangka waktu pengaruhnya terhadap tanaman bersifat sementara.

Pada Tabel 3 dapat dilihat bahwa pemberian pupuk biosilika tidak berbeda nyata terhadap jumlah malai, terlihat bahwa perlakuan tanpa pupuk biosilika cenderung memiliki jumlah malai lebih tinggi dibandingkan perlakuan lainnya. Hal tersebut diduga biosilika yang diberikan belum sepenuhnya terlarut oleh tanah karena pada masa inkubasi pupuk 
biosilika curah hujan rendah sehingga proses kimia tanah kurang optimal. Menurut Acquaah (2005), air berperan penting dalam tanah untuk pelarut nutrisi yang selanjutnya diperlukan untuk pertumbuhan tanaman. Biosilika merupakan pupuk yang berasal dari bahan organik sehingga membutuhkan proses kimia tanah untuk merubah unsur yang dapat diserap langsung oleh tanaman. Menurut Balittanah (2010), silika secara tidak langsung dapat meningkatkan $\mathrm{P}$ dalam tanah dan silika dapat mentranslokasikan $\mathrm{P}$ ke malai sehingga $\mathrm{P}$ lebih optimal untuk tanaman.

Tabel 3. Jumlah srisip dan jumlah malai pada 20 MST.

\begin{tabular}{lcc}
\hline \multicolumn{1}{c}{ Perlakuan } & $\begin{array}{c}\text { Jumlah } \\
\text { Srisip per } \\
\text { Rumpun }\end{array}$ & $\begin{array}{c}\text { Jumlah } \\
\text { Malai per } \\
\text { Rumpun }\end{array}$ \\
\hline Dosis Biosilika : & & \\
$0 \mathrm{~kg} / \mathrm{ha}$ & $73,65 \mathrm{a}$ & $322,76 \mathrm{a}$ \\
$100 \mathrm{~kg} / \mathrm{ha}$ & $66,45 \mathrm{a}$ & $278,36 \mathrm{a}$ \\
$200 \mathrm{~kg} / \mathrm{ha}$ & $64,32 \mathrm{a}$ & $257,49 \mathrm{a}$ \\
Dosis Paklobutrazol hgh: & & \\
0 ppm & $67,31 \mathrm{a}$ & $304,40 \mathrm{a}$ \\
$1250 \mathrm{ppm}$ & $70,11 \mathrm{a}$ & $279,98 \mathrm{a}$ \\
1500 ppm & $67,00 \mathrm{a}$ & $274,23 \mathrm{a}$ \\
\hline
\end{tabular}

Keterangan: Nilai rata-rata perlakuan yang diikuti oleh huruf yang dan pada kolom yang sama menunjukkan tidak berbeda nyata berdasarkan uji jarak berganda Duncan pada taraf $5 \%$.

Silika dapat meningkatkan ketersediaan unsur hara P dalam tanah (Warta Penelitian dan Pengembangan Pertanian, 2011). Pada hasil analisis tanah awal unsur hara $\mathrm{P}$ yang tersedia untuk tanaman sudah sangat tinggi. Hal tersebut diduga perlakuan biosilika yang memiliki peran dalam meningkatkan unsur hara $\mathrm{P}$ dalam tanah tidak memberikan pengaruh yang nyata atau memberikan pengaruh yang hampir sama pada setiap perlakuannya terhadap jumlah malai per rumpun hanjeli.

Perlakuan konsentrasi paklobutrazol terhadap tanaman hanjeli tidak memberikan pengaruh nyata terhadap jumlah malai per rumpun. Menurut Watson (2006), tanaman yang diberikan paklobutrazol akan menghasilkan fotosintat yang semula digunakan untuk pertumbuhan vegetatif nantinya akan digunakan untuk pertumbuhan generatif. Kemampuan tanaman dalam menghasilkan malai ditentukan oleh banyaknya anakan serta faktor status air tanah selama masa vegetatif.
Ketersediaan air yang cukup pada seluruh fase tumbuh tanaman membuat pertumbuhan tunas relatif sama sehingga munculnya malai pun relatif sama (Budi, 1998 dalam Ruminta dkk., 2017).

Bobot Biji per Rumpun, Hasil, dan Rendemen Biji Pecah Kulit. Pada Tabel 4 menunjukkan secara mandiri biosilika tidak memberikan pengaruh terhadap bobot biji per rumpun dan hasil. Menurut Nurmala $d k k$. (2016), secara tidak langsung silika organik meningkatkan ketersediaan $\mathrm{P}$ dalam tanah. Hal tersebut sejalan dengan pernyataan Hardjowigeno (2007) untuk pertumbuhan dan produksi (bunga, buah dan biji) tanaman memerlukan unsur P. Hasil analisis tanah awal menunjukkan bahwa unsur $\mathrm{P}$ sudah cukup tinggi sehingga biosilika tidak memberikan respon yang berbeda pada setiap perlakuan. Menurut Agustina dkk. (2007), umur panen berpengaruh terhadap polong, bobot biji bernas, dan biji keriput pada tanaman kacang tanah. Menurut Farida (2012), terjadi perbedaan berat biji sorgum pada berbagai umur panen. Pada umur panen 65 HST berat biji sorgum posisi ujung 0,47 g sedangkan pada masak fisiologis (90 HST) pada posisi ujung berat kering sebesar 1,58 g.

Perlakuan paklobutrazol tidak memberikan pengaruh nyata terhadap bobot biji per rumpun dan hasil (ton/ha). Hal tersebut disebabkan paklobutrazol menghambat hormon giberelin sehingga menghasilkan cabang yang pendek sehingga tidak ada pengaruhnya dengan bobot biji per rumpun. Menurut Harpitaningrum $d k k$. (2014), efektivitas pemberian paklobutrazol dipengaruhi oleh jumlah paklobutrazol yang diterima dan diserap oleh tanaman. Hal tersebut diduga konsentrasi pada percobaan ini kurang sehingga tidak memberikan respon bagi tanaman.

Hasil pengujian pengaruh mandiri dosis biosilika dan konsentrasi paklobutrazol terhadap rendemen biji pecah kulit dapat dilihat pada Tabel 4. Hasil analisis tersebut menunjukkan bahwa perlakuan pupuk biosilika dan paklobutrazol tidak terjadi interaksi terhadap rendemen biji pecah kulit. Pemberian perlakuan biosilika secara mandiri tidak memberikan pengaruh nyata terhadap rendemen bij pecah kulit.

Pemberian paklobutrazol tidak berpengaruh nyata disebabkan pengaplikasian paklobutrazol dilakukan saat curah hujan cukup tinggi sehingga efek paklobutrazol hanya sementara. Menurut Marshel dkk. (2015), 
paklobutrazol merupakan zat pengatur tumbuh menghambat kerja hormon giberelin sehingga membentuk cabang yang panjang bukunya lebih pendek. Menurut Chaney (2004), fungsi utama giberelin adalah menstimulasi perpanjangan sel.

Tabel 4. Bobot biji, hasil dan rendemen biji pecah kulit (RBPK).

\begin{tabular}{lrrr}
\hline \multicolumn{1}{c}{ Perlakuan } & $\begin{array}{c}\text { Bobot Biji per } \\
\text { Rumpun (g) }\end{array}$ & $\begin{array}{c}\text { Hasil } \\
(\text { Ton/Ha })\end{array}$ & $\begin{array}{c}\text { RBPK } \\
(\%)\end{array}$ \\
\hline Dosis Biosilika: & & & \\
$0 \mathrm{~kg} / \mathrm{ha}$ & $125,11 \mathrm{a}$ & $2,998 \mathrm{a}$ & $45,22 \mathrm{a}$ \\
$100 \mathrm{~kg} / \mathrm{ha}$ & $110,21 \mathrm{a}$ & $2,977 \mathrm{a}$ & $49,67 \mathrm{a}$ \\
$200 \mathrm{~kg} / \mathrm{ha}$ & $82,09 \mathrm{a}$ & $2,983 \mathrm{a}$ & $51,00 \mathrm{a}$ \\
Konsentrasi Paklobutrazol : & & \\
0 ppm & $91,46 \mathrm{a}$ & $2,951 \mathrm{a}$ & $40,56 \mathrm{a}$ \\
$1250 \mathrm{ppm}$ & $113,48 \mathrm{a}$ & $2,982 \mathrm{a}$ & $59,00 \mathrm{a}$ \\
$1500 \mathrm{ppm}$ & $112,47 \mathrm{a}$ & $2,980 \mathrm{a}$ & $46,33 \mathrm{a}$ \\
\hline
\end{tabular}

Keterangan: Nilai rata-rata perlakuan yang diikuti oleh huruf yang dan pada kolom yang sama menunjukkan tidak berbeda nyata berdasarkan uji jarak berganda Duncan pada taraf $5 \%$.

\section{Kesimpulan}

Tidak terdapat interaksi antara perlakuan pupuk biosilika dan paklobutrazol terhadap komponen pertumbuhan dan hasil hanjeli panen awal. Pengaruh dosis biosilika dan konsentrasi paklobutrazol secra mandiri tidak berpengaruh terhadap komponen pertumbuhan dan hasil hanjeli panen awal (matang kuning). Hal ini disebabkan curah hujan yang rendah pada saat aplikasi biosilika dan curah hujan yang tinggi pada saat aplikasi paclobutrazol.

\section{Daftar Pustaka}

Acquaah, G. 2005. Principles of Crop Production. Theory, Technique, and Technology. Pearson, Prentice Hall. New Jersey

Agustina A., Rahmianna, A. Taufiq, dan E. Yusnawan. 2007. Hasil polong dan kualitas biji kacang tanah pada tanah dengan kadar air dan umur panen berbeda. Penelitian Pertanian Tanaman Pangan. Balai Penelitian Kacang-Kacangan dan Umbi-Umbian. Jawa Timur.

Aztrina, A., A. M. Luthfi, dan K. Harso. 2014. Pengaruh Paclobutrazol Terhadap Jumlah
Klorofil, Umur Berbunga, dan Umur Panen Dua Varietas Sorgum (Sorghum bicolor (L.) Moench). Jurnal Agroekoteknologi, 2(4): 1296-1299.

Badan Pusat Statistik. 2015. Survei Sosial Ekonomi Nasional oleh Badan Pusat Statistik 2015.

Balittanah (Balai Penelitian Tanah). 2010. Warta Penelitian dan Pengembangan Pertanian. Vol. 33 No. 3 hal. 12-13. Balittanah, Bogor.

Chaney, E. R. 2004. Paclobutrazol: More Than Just a Growth Retardant. Pro-Hort Conference, Peoria, Illinois, February 4th. Department of Forestry and Natural Resources. Purdue University.

Farida, U. 2012. Pengaruh Letak Biji pada Malai terhadap Kualitas Benih pada Berbagai Umur Penen Sorgum (Sorghum bicolor L.). Jurusan Biologi Fakultas Sains dan Teknologi Universitas Islam Negeri Maulana Malik Ibrahim. Malang

Hardjowigeno, S. 2007. Ilmu Tanah. Akademika Pressindo. Jakarta.

Harpitaningrum, P., I. Sungkawa, dan S. Wahyuni. 2014. Pengaruh konsentrasi paklobutrazol terhadap pertumbuhan dan hasil tanaman mentimun (Cucumis sativus L.) kulitvar venus. Jurnal Agrijati, 25(1).

Kartika, E dan S, Ilyas. 1994. Pengaruh tingkat kemasakan benih dan metode konservasi terhadap vigor benih dan vigor kacang jogo (Phaseolus vulgaris L.) . Bul. Agron., 22 (2): 44-59.

Makarim, A. K, E. Suhartatik, dan A. Kartohardjono. 2007. Silkon: Hara Penting pada Sistem Produksi Padi. Litbang. Iptek Tanaman Pangan, 2(2).

Marimbing, R. 2003. Respons pertumbuhan dan hasil padi gogo (Oryza sativa L.) terhadap pemberian paklobutrazol dan pupuk nitrogen. Eugenia, 9(3): 169-173.

Marshel, E., M. K. Bangun, L. A. P. Putri. 2015. Pengaruh Waktu Dan Konsentrasi Paclobutrazol Terhadap Pertumbuhan Bunga Matahari. Jurnal Agroteknologi, 3(3): 929-937.

Ningsih, R. dan R. Dwi. 2017. Application of paclobutrazol and micro inorganic fertilizer on the yield and seed quality of rice (Oryza sativa L.). Jurnal Agriprima, 1(1): 22-34.

Nurmala, $\mathrm{T}$ dan A. W. Irwan.2007. Pangan Alternatif Berbasis Serealia Minor. Giratuna. Bandung. 
Nurmala, T., Ruminta, dan A. Wahyudin. 2017. Respons pertumbuhan dan hasil tanaman hanjeli batu (Coix lacryma-jobi L) akibat pupuk silika cair dan paclobutrazol. Jurnal Kultivasi, 16(3): 478 - 481.

Nurmala, T. 1998. Serelia Sumber Karbohidrat Utama. Rineka Cipta. Jakarta.

Nurmala, T., A. Yuniarti, dan N. Syahfitri. 2016. Pengaruh berbagai dosis pupuk biosilika organik dan tingkat kekerasan biji terhadap pertumbuhan dan hasill tanaman hanjeli pulut. J. Kultivasi, 15(2): 133-142.

Nyakpa, M. Y., A. M. Lubis, M. A. Pulung, Amrah, A. Munawar, G. B. Hong, dan N. Hakim. 1988. Kesuburan Tanah. Universitas Lampung Press. Lampung.

Rai, Ny. dan Poerwanto R. 2008. Memproduksi Buah di Luar Musim. Lily Publisher. Yogyakarta.

Rubiyanti, N. dan Y. Rochayat. 2015. Pengaruh konsentrasi paklobutrazol dan waktu aplikasi terhadap mawar batik (Rosa hybrida L.). Agric. Sci. J.,-4(4) : 48-53.

Ruminta, Y. Yuwariah dan N. Sabrina. 2017. Respon pertumbuhan dan hasil tanaman hanjeli (Coix lacryma-jobi L.) terhadap jarak tanam dan pupuk pelengkap cair. Jurnal Agrikultura 28 (2): 82-89.

Simanjuntak, N.C., E.S. Bayu, dan I. Nuriadi. 2014. Uji Efektivitas Pemberian Paclobutrazol Terhadap Keseimbangan Pertumbuhan Tiga Varietas Kacang Tanah (Arachis hypogaea L.). Agroekoteknologi, 2(1).

Sutoyo. 2011. Fotoperiode dan pembungaan tanaman. Buana Sains, 11(2): 137-144.

Warta Penelitian dan Perkembangan Pertanian. 2011. Sumber Hara Silika untuk Pertanian. 33 (3).

Watson, W. 2006. The Effect of Paclobutrazol Treatment on Starch Content, Mychorizal Colonization, and Fine Root Density of White Oaks (Querus alba L.). Arboriculture and Urban Forestry, 32(3).

Wicaksono, F. Y., Y. Maxiselly, O. Mulyani, dan M. I. Janitra. 2016. Pertumbuhan dan hasil gandung (Triticum aestivum L.) yang diberi perlakuan pupuk silikon dengan dosis yang berbeda di dataran medium Jatinangor. Jurnal Kultivasi, 15(3): 179-186. 